\title{
Flexural Strength Behaviour of Apa (Afzeliabipindensis) Reinforced Stabilized Lateritic Soil Beam
}

\author{
Ozigi, P.B. ${ }^{1}$, Tuleun, L.Z. ${ }^{*}$, and Jimoh, A.A. ${ }^{1}$
}

\begin{abstract}
This paper reports on the flexural strength behaviour of Apa reinforced stabilized lateritic soil beams. The potential of using timber as a reinforcement material is because timber is abundant, cheap and locally available compared to conventional steel. Apa timber possess a tensile strength of $68.34 \mathrm{~N} / \mathrm{mm}^{2}$. Experimental and Finite Element Analysis using ANSYS 15 were carried out to determine the flexural strength of Apa reinforced lateritic soil beams. The results showed an increase in the load-bearing capacity with increase in the percentage area of Apa reinforcement used in Lateritic soil beams. BS 8110-1:1997 requires that area of reinforcement for beams should not exceed 4\%. At 4 percent area, the flexural strength of the Apa reinforced lateritic soil beams (ALB) was $0.763 \mathrm{~N} / \mathrm{mm}^{2}$ with corresponding load capacity of $3.435 \mathrm{kN}$ which is slightly higher than the steel reinforced lateritic soil beams (SLB) of $0.740 \mathrm{~N} / \mathrm{mm}^{2}$ with corresponding load capacity of $3.329 \mathrm{kN}$ obtained in the report.
\end{abstract}

Keywords: Lateritic soil; Apa (Afzeliabipindensis) reinforced soil beam; flexural strength.

\section{Introduction}

Laterite is a group of highly weathered soil formed by the concentration of hydrated oxides of iron, and aluminium [1]. Laterites and lateritic soils form a group comprising a wide variety of red, brown, and yellow fine-grained residual soils of light texture as well as nodular gravels and cemented soils indicating the presence of iron oxide which makes laterite chemically written as $\mathrm{Fe}_{2} \mathrm{O}_{3}-\mathrm{Al}_{2} \mathrm{O}_{3}-\mathrm{SiO}_{2}-\mathrm{H}_{2} \mathrm{O}[2,3]$. The term Laterite is derived from the Latin word 'later' meaning brick. It was first used in 1807 by Buchanan to describe a red iron-rich material found in the southern part of India. Laterites are widely distributed throughout the world in the regions with high rainfall, especially in the inter-tropical areas of Africa, Australia, India, South-East Asia, and South America where they are generally present just below the surface of grasslands or forest clearings. The utilization of laterites enables the provision of low-cost houses and other rural infrastructures. However, laterites have not been extensively used in constructing medium to large-size building structures. This is probably due to lack of adequate data needed in the analysis and design of structures built of lateritic soils.

\footnotetext{
${ }^{1}$ Department of Civil Engineering, University of Ilorin, Ilorin, NIGERIA

* Corresponding author; email: tuleun@gmail.com
}

Note: Discussion is expected before July, $1^{\text {st }} 2020$, and will be published in the "Civil Engineering Dimension", volume 22, number 2, September 2020.

Received 17 November 2019; revised 27 January 2020; accepted 04 May 2020
Apa is grown in Ajase Ipo, in Kwara State, within North Central zone of Nigeria. It is readily available and extensively used in this area and other places in Nigeria. According to Nigerian Standard Code of Practice, NCP 2 [4], Apa a very durable hardwood, has an excellent resistance capacity to attack by termite. The timber is readily available in the Savannahs and high forests. Environmental condition, weather condition, and the soil affect the growth of trees as well as their strength properties [5]. Apa timber has good machining qualities, it is sandy in texture. Its uses include flooring, furniture, decking, stair rails, and other conventional construction [6]. The strength properties of Apa timber perpendicular to the grain is much lower than its strength properties when parallel to the grain. Apa timber belongs to strength class of D30 -D70 as stated in BS 5268:2002 which indicates that Apa timber is a hardwood and can be used for structural applications like decking, roof constructions, reinforcements in earth and concrete matrix, timber bridges, beams, rafters, and railway sleepers. Due to its relatively high tensile property, it can be used to reinforce the soil for construction of stable structures [7].

Research conducted by Richard [8], on the use of sugarcane bagasse fiber as a reinforcement material in cement-lateritic beam revealed a decrease in the peak load required to cause maximum deflection, as the replacement levels increased. The average maximum peak load-deflection of sugarcane bagasse fibercement-lateritic beam was lower than the conventional beam by $17.5 \%$. They also observed that the control beam specimens exhibited a higher stiffness than sugarcane bagasse fiber- cement-lateritic beam, 
and a similar behaviour pattern up to $20 \mathrm{KN}$. Based on the research conducted, they concluded that sugarcane bagasses laterised concrete beam can be designed for a grade of $20 \mathrm{MPa}$ using the requirements contained in BS 8110 Part 1-1997 for design of structures.

Graeme [9] stated that most parts of Africa have laterite deposits due to the possible factors that encourage its formation. Traditional houses seen in rural part of Africa are usually made using laterite. Openings in mud building such as windows and doors are usually framed and supported by exposed timber which may fail due to exposure to termites and other environmental conditions. There is a need for a suitable structural member like reinforced stabilized lateritic beams to replace the exposed timber. Also, considering the high cost of steel reinforcement, timber such as Apa timber can be used in place of the steel bars to provide the necessary strength.

This study is aimed at investigating the flexural strength of stabilized lateritic soil beam reinforced with Apa timber in accordance with the BS EN 123905 (Testing hardened concrete-Flexural strength of test specimens) [10]. Comparative performance study will be carried to examine the flexural strength behaviour of Apa, steel, and unreinforced lateritic soil beam.

\section{Materials and Methodology}

\section{Materials}

The materials used for this experiment were Apa timber, steel bars, timber Stirrups, laterite, ordinary portland cement (OPC), and water. The Apa timbers were obtained from saw mill marketers at Tanke, in Ilorin area of Kwara state, Nigeria. The various steel bars and OPC were also gotten from marketer at Tanke, llorin. The lateritic material was dogged from a borrowed pit within the university of Ilorin campus.

\section{Tests for Physical Properties of Laterite}

Particle size distribution, specific gravity, moisture content, atterberg limit, and compaction test were carried out on the laterite sample in accordance with BS 1377: Part 2 [11]

\section{Tension Parallel to the Grain of Apa timbers}

The specimen shape and the test procedure for this experiment was carried out in accordance with the BS 373 [12]. Twenty (20) specimens of Apa timber obtained from the sawmill were formed and dimensioned as illustrated in Figure 1 to determine the tensile strength parallel to the grain. Figures 2 and 3 showed the tensile test set up and failure mode respectively.

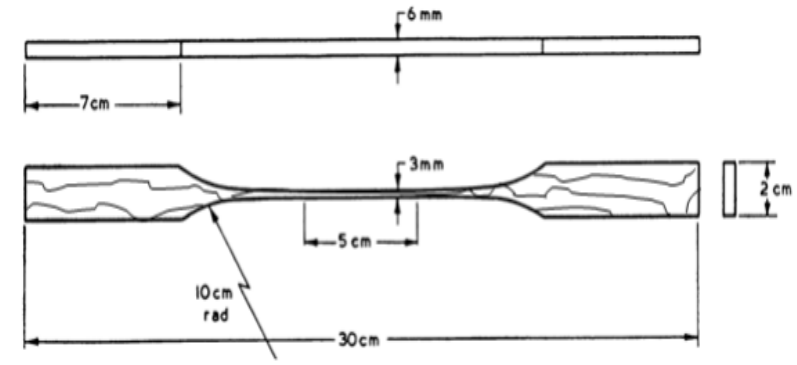

Figure 1. Test Piece for Tension Parallel to the Grain Test

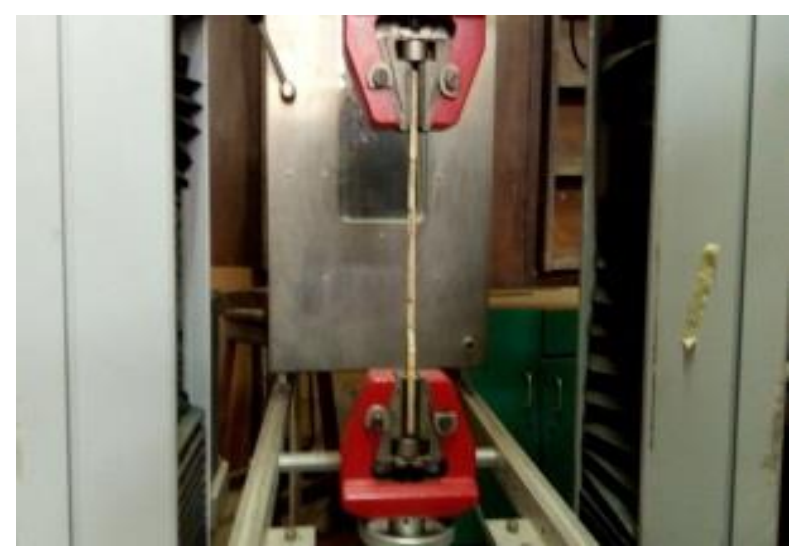

Figure 2. Tensile Strength Set Up

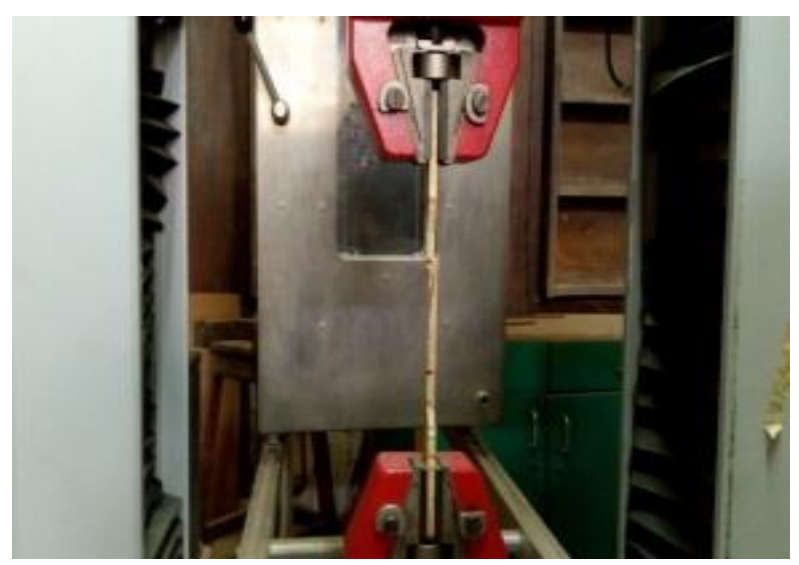

Figure 3. Tensile Failure Mode

\section{Test for Compressive Strength of Stabilized Lateritic Cubes}

Test for compressive strength of stabilized lateritic cubes was carried out in accordance with BS 1881 Part 116 [13]. Five (5) stabilized laterite cubes of size $150 \mathrm{~mm} \times 150 \mathrm{~mm} \times 150 \mathrm{~mm}$ were moulded according to the mix proportions in Table 1 using absolute volume method [14]. National building and road research institute (NBRRI) proposed the following specifications as requirements for laterite bricks: bulk density of $1810 \mathrm{~kg} / \mathrm{m}^{3}$, water absorption of $12.5 \%$, compressive strength of $1.65 \mathrm{~N} / \mathrm{mm}^{2}$, and durability of $6.9 \%$ with maximum cement content fixed at $5 \%$. The cubes were cured by covering using polythene sheets for 28 days before testing. 
Table 1. Mix Proportions for Stabilized Lateritic Cubes

\begin{tabular}{ccccccc}
\hline $\begin{array}{c}\text { No. of } \\
\text { S/N sample } \\
\mathbf{s}\end{array}$ & $\begin{array}{c}\text { Cemen } \\
\mathbf{t} \\
\text { content } \\
(\mathbf{6})\end{array}$ & $\begin{array}{c}\text { Mass of Mass of Mass of } \\
\text { cement laterite } \\
(\mathbf{k g})\end{array}$ & $\begin{array}{c}\text { (kg) } \\
\text { water } \\
\mathbf{( k g )}\end{array}$ & $\begin{array}{c}\text { cement } \\
\text { ratio }\end{array}$ \\
\hline $\mathbf{1}$ & 5 & 5 & 1.101 & 22.02 & 3.096 & 2.812 \\
\hline
\end{tabular}

\section{Reinforcement Preparation for Flexural Strength Test}

Four longitudinal square Apa timber rods each 460 $\mathrm{mm}$ long of square cross-sections $(12 \mathrm{~mm}, 16 \mathrm{~mm}$, and $20 \mathrm{~mm}$ ) and $8 \mathrm{~mm}$ link bars were tied together with binding wires as shown in Figure 4. Cover of $20 \mathrm{~mm}$ is provided. Steel reinforcement rods for control beams were also prepared similarly as shown in Figure 5.

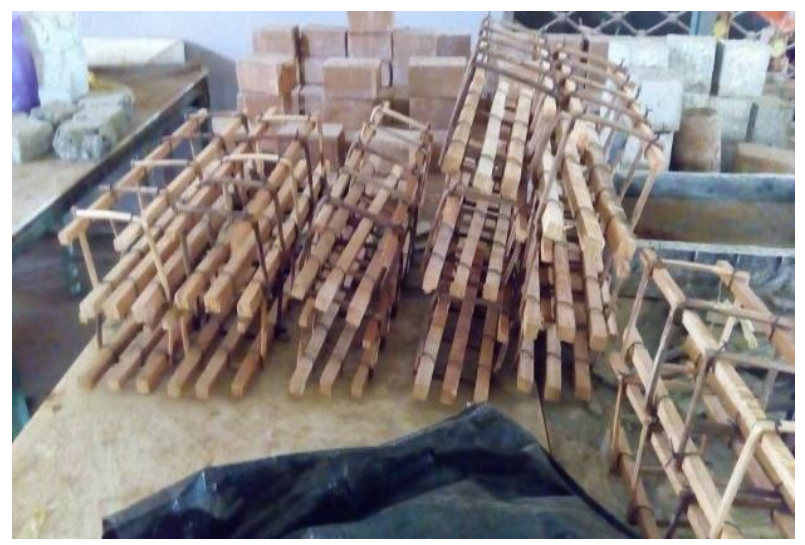

Figure 4. Apa Reinforcement

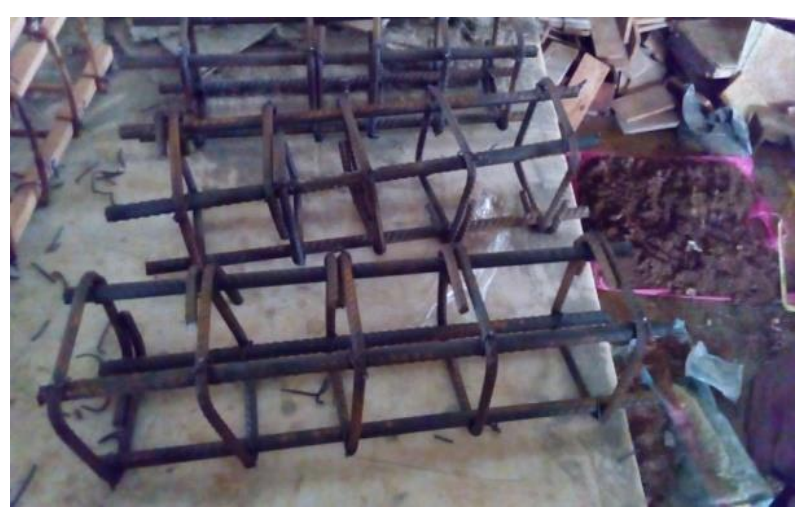

Figure 5. Steel Reinforcment

\section{Beam Detailing}

Figure 6 shows a typical reinforcement detail of the stabilized lateritic beams.

\section{Stabilized Lateritic Soil Preparation}

The preparation of Stabilized lateritic soil was carried out after reinforcements were arranged. The materials used were ordinary Portland cement (Dangote brand) and laterite.

\section{Casting of Lateritic Soil Beam}

Forty-five (45) stabilized laterite beams of length 500 $\mathrm{mm}$ and size $150 \mathrm{~mm} \times 150 \mathrm{~mm}$ were moulded according to the mix proportions in Table 3 using absolute volume method [15], by filling the mould in five layers and each layer was given 25 blows of compaction

Table 2. Description of Test Beams

\begin{tabular}{|c|c|c|c|c|c|c|c|c|}
\hline Label & $\mathrm{h}(\mathrm{mm})$ & $\mathrm{d}(\mathrm{mm})$ & As $\left(\mathrm{mm}^{2}\right)$ & $\frac{100 A s}{b h}(\%)$ & $\begin{array}{c}\text { Barsize } \\
(\mathrm{mm})\end{array}$ & No. & $\begin{array}{c}\text { Stirrups } \phi \\
(\mathrm{mm})\end{array}$ & $\mathrm{s}(\mathrm{mm})$ \\
\hline$\overline{\mathrm{ALB1}}$ & 150 & 116 & 225 & 1 & 12 & 4 & 8 & 90 \\
\hline ALB2 & 150 & 114 & 450 & 2 & 16 & 4 & 8 & 88.5 \\
\hline ALB3 & 150 & 112 & 675 & 3 & 20 & 4 & 8 & 87 \\
\hline ALB4 & 150 & 112 & 900 & 4 & 20 & 5 & 8 & 87 \\
\hline SLB & 150 & 116 & 180 & 0.8 & 12 & 4 & 8 & 90 \\
\hline ULB & 150 & - & - & - & - & - & - & - \\
\hline
\end{tabular}

Note: ALB is the Apa Timber Reinforced Lateritic Beam, ULB is the Unreinforced Lateritic Beam SLB is the Steel Reinforced Lateritic Beam, $h$ is the thickness of beam $(\mathrm{mm}) d$ is the effective depth $(\mathrm{mm})$, As is the area of reinforcement $\left(\mathrm{mm}^{2}\right), \phi$ is the bar size [square] ( $\mathrm{mm})$, $\mathrm{s}$ is the spacing of stirrups $(\mathrm{mm})$.

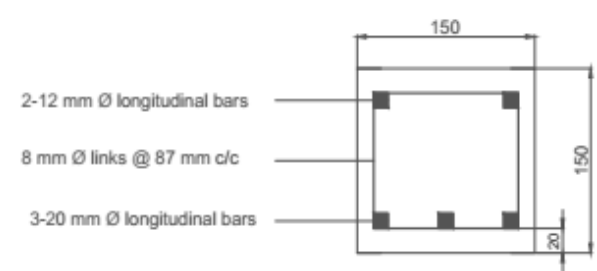

Section $Y-Y$

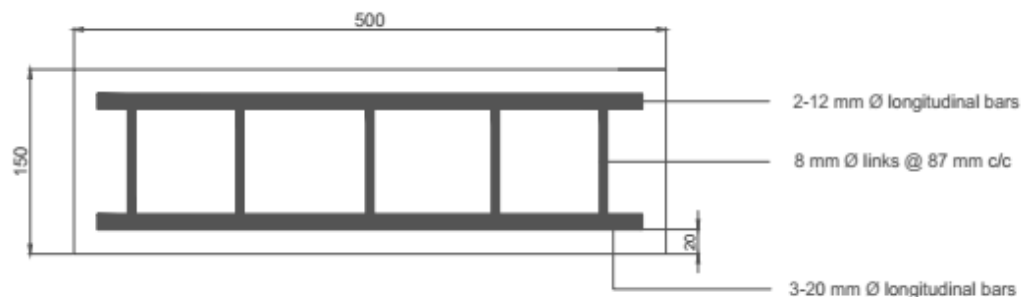

Section X-X

Figure 6. Apa Reinforced Lateritic Beams 
using a standard rammer of weight $4.5 \mathrm{~kg}$ falling from a height of $0.45 \mathrm{~m}$ according to BS 1377: Part 2: 1990 [11]. The freshly moulded beams were carefully extruded on a clean and flat surface as shown in Figure 7 and Figure 8, and were cured by covering the samples with polythene sheet for 28 days before testing

Table 3. Mix Proportions for Stabilized Lateritic Beams

\begin{tabular}{ccccccc}
\hline $\mathrm{S} / \mathrm{N}_{\text {samples }} \begin{array}{c}\text { No. of } \\
\text { content } \\
(\%)\end{array}$ & $\begin{array}{c}\text { cement } \\
(\mathrm{kg})\end{array}$ & $\begin{array}{c}\text { Mass of Mass of } \\
\text { laterite } \\
(\mathrm{kg})\end{array}$ & $\begin{array}{c}\text { water/ } \\
\text { water } \\
(\mathrm{kg})\end{array}$ & $\begin{array}{c}\text { cement } \\
\text { ratio }\end{array}$ \\
\hline 1 & 27 & 5 & 33.075 & 661.5 & 93.015 & 2.812 \\
\hline
\end{tabular}

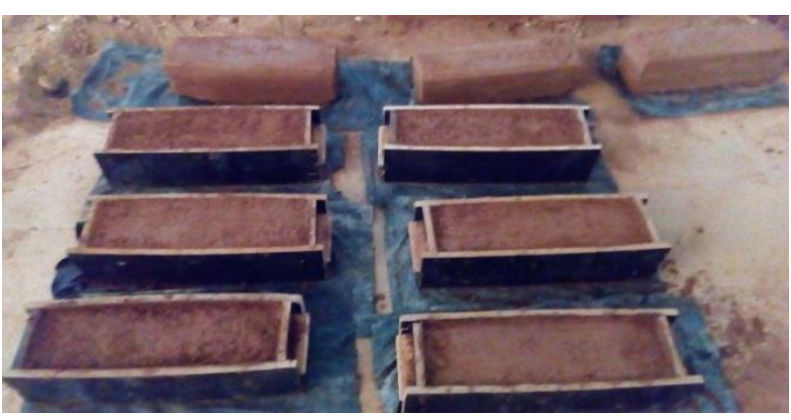

Figure 7. Beams in the Mould

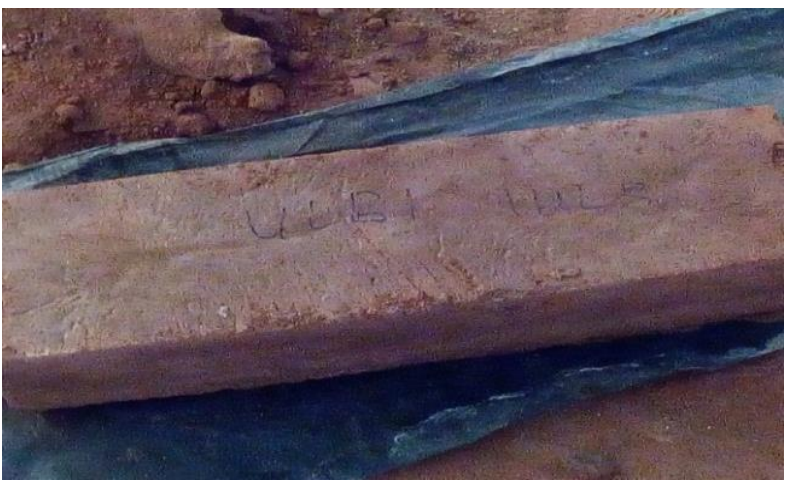

Figure 8. Demoulded Beam Sample

\section{Flexural strength test}

The test method (centre point loading) was carried out in accordance with the BS EN 12390-5:2000 [10]. It was ensured that the reference direction of the loading is perpendicular to the direction of the casting of the specimen as shown in Figure 9. A constant rate of stress with the range $10 \mathrm{~mm} / \mathrm{min}$ was applied. The flexural strength is given by the equation:

$f_{d}=\frac{3 \times F \times l}{2 \times d_{1} \times d_{2}^{2}}$

Where:

$\mathrm{f}_{\mathrm{d}}=$ flexural strength in megapascals (Newton per square millimetre $\left.\left(\mathrm{N} / \mathrm{mm}^{2}\right)\right)$;

$\mathrm{F}=$ the maximum load, in Newton $(\mathrm{N})$;

$1=$ the distance between the supporting rollers, in millimetres (mm).

$\mathrm{d}_{1}$ and $\mathrm{d}_{2}=$ the lateral dimensions of the cross-section, in millimetres.

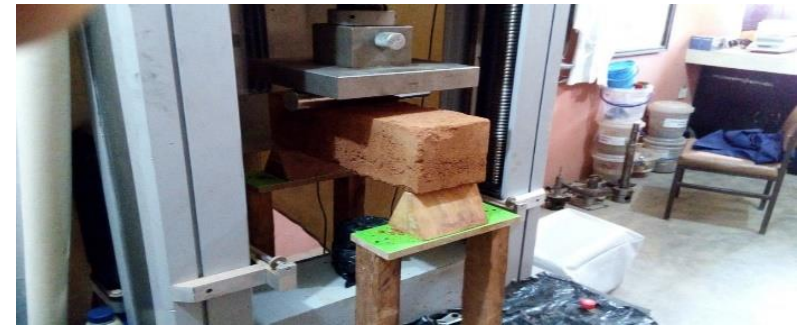

Figure 9. Flexural Test Arrangement

\section{Validation of Results}

Finite element analysis using ANSYS 15.0 was carried out to see the behaviour of Apa reinforced Lateritic beams when subjected to point load at the centre. This was carried out to validate the experimental results. The unreinforced, steel reinforced, and Apa reinforced Lateritic beams were modelled in ANSYS 15.0 using the standard geometry of the specimens. Material behaviour properties such as the modulus of elasticity (Young's modulus) and Poisson ratio gotten from the experimental results were inputted for computation. Triangular supports were modelled and fixed at $25 \mathrm{~mm}$ from the ends to have a clear span of $450 \mathrm{~mm}$ same as the laboratory experimental set up was done. Also, centre point load was applied in the middle of the clear span in the negative y-axis.

\section{Results and Discussion}

\section{Physical Properties of Steel and Laterite}

Y12, Y16 and Y20 steel rods had a yield strength value of $410 \mathrm{MPa}$ while the Y10 and Y8 steel rods had a yield strength value of $250 \mathrm{MPa}$. The index properties of the laterite used in the study are summarized in Table 4, while Figure 10 shows the particle size distribution curve of the laterite. The relationship between the dry density and moisture content is presented in Figure 11. The soil is classified in A-2-7 Subgroup of A-2 group according to AASHTO [15] classification which gives the usual types of significant constituent materials as silty or clayey gravel and sand, and the soil can be rated as good. The normal compaction curve for most laterite is depicted, indicating a maximum dry density (MDD) of 4.24 $\mathrm{g} / \mathrm{cm}^{3}$ and an optimum moisture content (OMC) of $14.06 \%$.

Table 4. Properties of the Laterite Used

\begin{tabular}{lc}
\hline Characteristic & Laterite \\
\hline Natural moisture content (\%) & 3.36 \\
Percentage passing BS No 200 sieve & 2.6 \\
(\%) & \\
Liquid limit (\%) & 51 \\
Plastic limit (\%) & 30.6 \\
Plasticity index (\%) & 20.4 \\
AASHTO classification & $\mathrm{A}-2-7$ \\
Maximum dry density (g/cm3) & 4.24 \\
Optimum moisture content (\%) & 14.06 \\
Specific gravity & 2.69 \\
Condition of sample & Air-dried \\
\hline
\end{tabular}




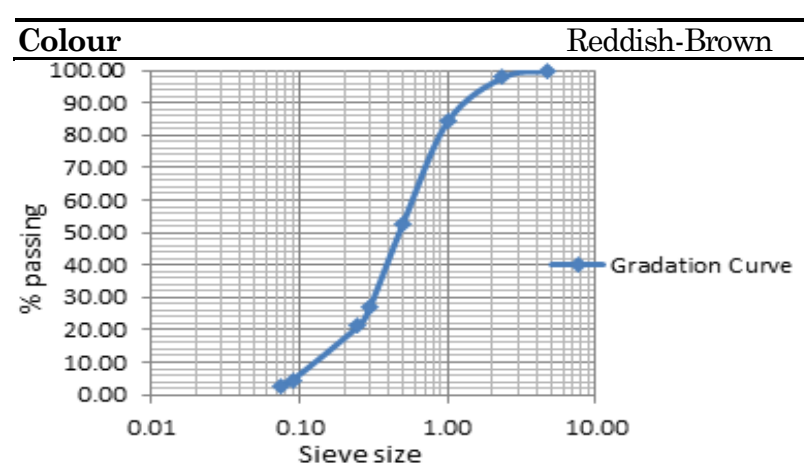

Figure 10. Particle Size Distribution Curve of the Laterite Used

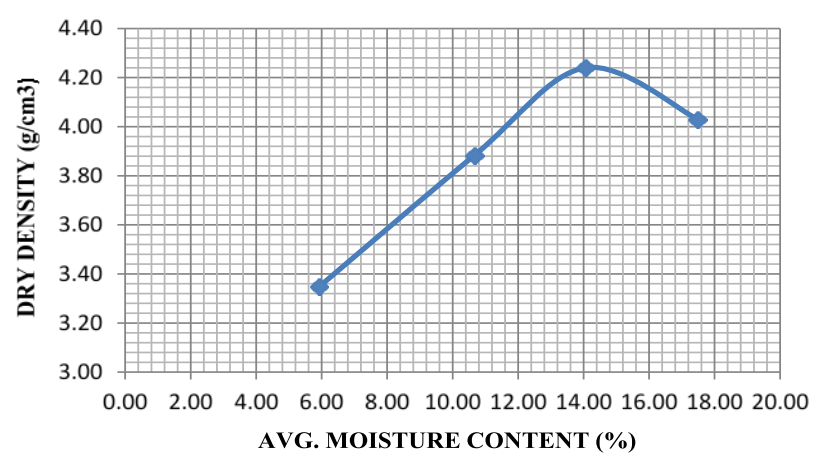

Figure 11. Dry Density Against Average Moisture Content

\section{Test Result of Tension Parallel to the Grain of Apa Timber}

Results of Tensile strength parallel to grain of Apa timber are presented in Table 5. The result of mean tensile strength at yield is $68.339 \mathrm{~N} / \mathrm{mm}^{2}$

Table 5. Tensile Strength Test Result for Apa Timber

\begin{tabular}{ccccc}
\hline S/N & $\begin{array}{c}\text { Stress }(\sigma) \\
\text { Yield at } \\
\left(\mathrm{N} / \mathrm{mm}^{2}\right)\end{array}$ & $\begin{array}{c}\text { Strain }(\varepsilon) \text { at } \\
\text { Yiel } \\
\mathrm{d}(\%)\end{array}$ & $\begin{array}{c}\text { Young's } \\
\text { Modulus } \\
\left(\mathrm{N} / \mathrm{mm}^{2}\right)\end{array}$ & $\begin{array}{c}\text { Energy to } \\
\text { Yield } \\
(\mathrm{N} . \mathrm{m})\end{array}$ \\
\hline Mean & 68.339 & 1.887 & 4321.217 & 1.005 \\
\hline
\end{tabular}

\section{Results of Compressive Strength for Stabilized Lateritic Soil Cubes}

The results of compressive for stabilized lateritic soil cubes are presented in Table 6, and Figure 12 shows the stress-strain curve. A linear increase in stress with corresponding increase in strain was observed. The mean compressive strength at yield point was $2.013 \mathrm{~N} / \mathrm{mm}^{2}$. The ultimate strain was 0.047 . Beyond the peak point, there was a rapid drop in stress-strain. However, further research should be carried out to better understand fracture mechanics of the lateritic specimens.

Table 6. Compressive Test Results for Stabilized Lateritic Soil Cubes

\begin{tabular}{ccccc}
\hline S/N & $\begin{array}{c}\text { Stress }(\sigma) \text { at } \\
\text { Yield } \\
\left(\mathrm{N} / \mathrm{mm}^{2}\right)\end{array}$ & $\begin{array}{c}\text { Strain }(\varepsilon) \\
\text { at Yield } \\
(\%)\end{array}$ & $\begin{array}{c}\text { Young's } \\
\text { Modulus } \\
\left(\mathrm{N} / \mathrm{mm}^{2}\right)\end{array}$ & $\begin{array}{c}\text { Energy to } \\
\text { Yield } \\
(\mathrm{N} . \mathrm{m})\end{array}$ \\
\hline Mean & 2.013 & 4.663 & 94.733 & 106.181 \\
\hline
\end{tabular}

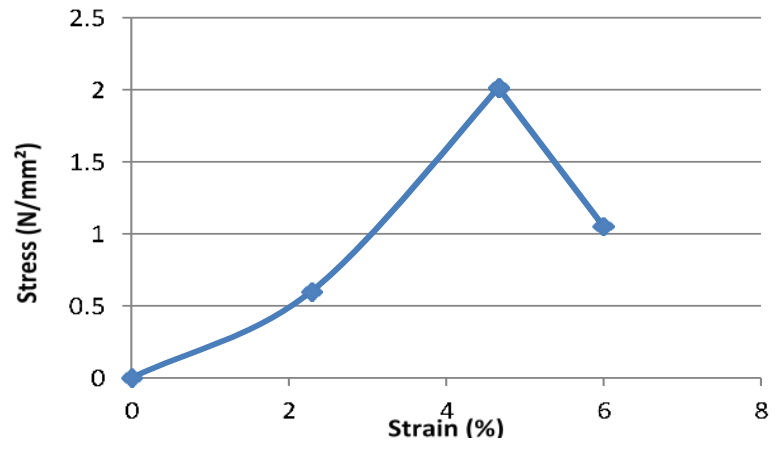

Figure 12. Stress-strain Curve for Stabilized Lateritic Soil Cubes

Results of Flexural Strength for Unreinforced, Steel, and Apa Reinforced Lateritic Soil Beams

The experimental load results of the three-point flexural test on the unreinforced and steel reinforced lateritic soil beams are presented in Table 7. The failure load for the unreinforced lateritic beam was $873.6 \mathrm{~N}$, while for the steel reinforced lateritic beam; the failure load was $3329.4 \mathrm{~N}$. The flexural strength for the unreinforced lateritic beam was $0.194 \mathrm{~N} / \mathrm{mm}^{2}$, while for the steel reinforced lateritic beam; the flexural strength was $0.740 \mathrm{~N} / \mathrm{mm}^{2}$. The crack pattern of the steel reinforced lateritic soil beam started from both supports up to the point of application of load in a diagonal direction, while the unreinforced lateritic beam failed utterly. This showed that steel improved the flexural strength of the beams. The value of the flexural strength $(0.194$ $\mathrm{N} / \mathrm{mm}^{2}$ ) for the unreinforced lateritic beam was less than $0.79 \mathrm{~N} / \mathrm{mm}^{2}$ obtained for un reinforced lateritic beam with $10 \%$ cement content as reported by Sackey [16].

The experimental load results of the three-point flexural test on the Apa reinforced lateritic soil beams are presented in Table 8. From the failure loads, it was observed that the higher the percentage of Apa timber, the higher the load required to rupture the beams. While the flexural strength also increased from $0.364 \mathrm{~N} / \mathrm{mm}^{2}$ to $0.763 \mathrm{~N} / \mathrm{mm}^{2}$ with an increase in percentage area of Apa reinforcement. The flexural strength of lateritic soil beam with $4 \%$ area of Apa reinforcement $\left(0.763 \mathrm{~N} / \mathrm{mm}^{2}\right)$ was a little bit higher than the steel reinforced lateritic soil beam $(0.740$ $\mathrm{N} / \mathrm{mm}^{2}$ ), and was less than $0.85 \mathrm{~N} / \mathrm{mm}^{2}$ obtained for polypropylene reinforced lateritic beams with $10 \%$ cement content as reported by Sackey [16]. The failure pattern is the same as the steel reinforced specimen. From the failure mode, it was observed that the number of cracks and deflection of the steel reinforced lateritic soil beam increased as a result of steel having a higher modulus of elasticity compared to timber. The flexural load-deflection curve of control beams and Apa reinforced lateritic soil beams are presented in Figure 13. As presented in Figure 13, the 
Mode of failure of the lateritic soil beam (ALB2) containing $2 \%$ area of Apa differed from the others specimens in terms of its failure rate; the failure rate results obtained for this particular specimen (ALB2) may have being faulty due to an experimental or sampling error during batching process.

Table 7. Flexural Test Result for Unreinforced and Steel Reinforced Lateritic Soil Beams

\begin{tabular}{lcrrrr}
\hline Label & $\begin{array}{c}\text { Specimen } \\
\mathrm{S} / \mathrm{N}\end{array}$ & $\begin{array}{r}\text { Density } \\
\left(\mathrm{kg} / \mathrm{m}^{3}\right)\end{array}$ & $\begin{array}{c}\text { Failure } \\
\text { load } \\
(\mathrm{N})\end{array}$ & $\begin{array}{r}\text { Deflection } \\
\text { at peak } \\
(\mathrm{mm})\end{array}$ & $\begin{array}{r}\text { Flexural } \\
\text { Strength } \\
\left(\mathrm{N} / \mathrm{mm}^{2}\right)\end{array}$ \\
\hline ULB & Mean & 1806.039 & 873.600 & 3.754 & 0.194 \\
SLB & Mean & 1942.454 & 3329.400 & 12.205 & 0.740 \\
\hline
\end{tabular}

Table 8. Flexural Test Result for Apa (Afzeliabipindensis) Reinforced Lateritic Soil Beam

\begin{tabular}{llrrrc}
\hline Label & $\begin{array}{c}\text { Specimen } \\
\mathrm{S} / \mathrm{N}\end{array}$ & $\begin{array}{r}\text { Density } \\
\left(\mathrm{kg} / \mathrm{m}^{3}\right)\end{array}$ & $\begin{array}{r}\text { Failure } \\
\text { load (N) }\end{array}$ & $\begin{array}{c}\text { Deflection } \\
\text { at peak } \\
(\mathrm{mm})\end{array}$ & $\begin{array}{r}\text { Flexural } \\
\text { Strength } \\
\left(\mathrm{N} / \mathrm{mm}^{2}\right)\end{array}$ \\
\hline ALB1 & Mean & 1817.086 & 1636.200 & 12.189 & $\mathbf{0 . 3 6 4}$ \\
ALB2 & Mean & 1884.907 & 2181.400 & 5.999 & $\mathbf{0 . 4 8 5}$ \\
ALB3 & Mean & 1943.218 & 2479.400 & 9.803 & $\mathbf{0 . 5 5 1}$ \\
\hline ALB4 & Mean & $\mathbf{1 8 6 6 . 1 1 2}$ & $\mathbf{3 4 3 5 . 0 0 0}$ & $\mathbf{1 1 . 8 2 2}$ & $\mathbf{0 . 7 6 3}$ \\
\hline
\end{tabular}

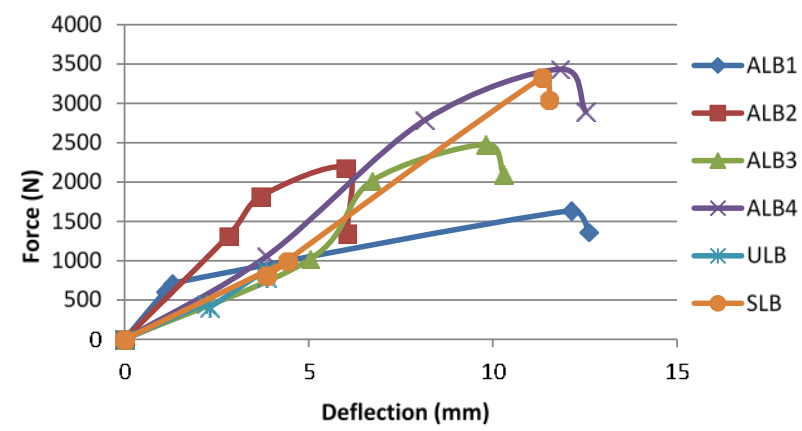

Figure 13. Load-deflection Curve for the Unreinforced, Steel, and Apa Reinforced Soil Beams

\section{Modelling of Test Beams with ANSYS 15.0}

A typical representation of the flexural strength of the unreinforced, steel reinforced, and Apa reinforced lateritic soil beams obtained using ANSYS 15.0 software is presented in Figure 14.

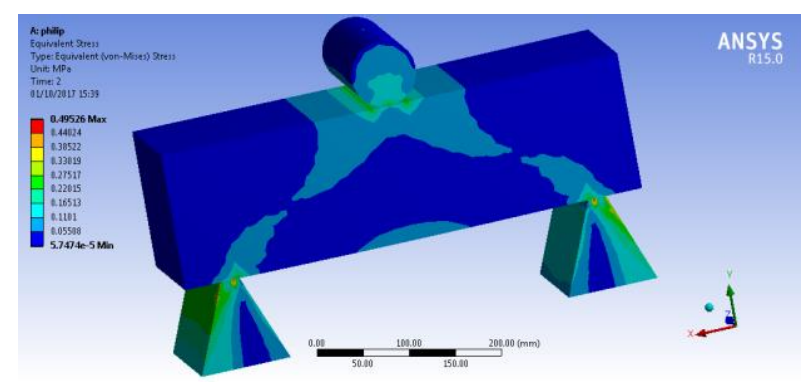

Figure 14. Typical (von - mises) Stress for a Modelled Beam

These results from the analysis performed using ANSYS 15 also followed the same trend with the laboratory results which showed that the higher the percentage area of Apa reinforcements used in Lateritic soil beams, the higher the flexural strength, and at percentage area of 4 , the flexural strength of the Apa reinforced lateritic soil beams was slightly higher than the steel reinforced lateritic soil beams at $0.8 \%$. The ANSYS flexural strengths were compared with experimental flexural strengths in Table 9 . The results value obtained from the experimental flexural strength test can be multiplied with the average factor $(\mathrm{FA} / \mathrm{FE})$ of 2.63 to obtain ANSYS flexural strength, since the pattern of flexural strength development between the ANSYS results and experimental result are in tandem for all the various specimen samples (ALB1, ALB2, ALB3, ALB4).

Table 9. Comparison between ANSYS flexural strengths and experimental flexural strengths

\begin{tabular}{|c|c|c|c|c|c|}
\hline Label & $\begin{array}{c}\mathrm{d} \\
(\mathrm{mm})\end{array}$ & $\begin{array}{c}\mathrm{As} \\
\left(\mathrm{mm}^{2}\right)\end{array}$ & $\begin{array}{c}\text { Experimental } \\
\text { Flexural } \\
\text { Strength } \\
\left(\mathrm{N} / \mathrm{mm}^{2}\right)\left(\mathrm{F}_{\mathrm{E}}\right) \\
\end{array}$ & $\begin{array}{c}\text { ANSYS } \\
\text { Flexural } \\
\text { Strength } \\
\left(\mathrm{N} / \mathrm{mm}^{2}\right)\left(\mathrm{F}_{\mathrm{A}}\right) \\
\end{array}$ & $\frac{F_{A}}{F_{E}}$ \\
\hline ALB1 & 116 & 225 & 0.364 & 0.931 & 2.56 \\
\hline ALB2 & 114 & 450 & 0.485 & 1.248 & 2.57 \\
\hline ALB3 & 112 & 675 & 0.551 & 1.463 & 2.66 \\
\hline ALB4 & 112 & 900 & 0.763 & 2.094 & 2.74 \\
\hline Average & & & & & 2.63 \\
\hline \multicolumn{6}{|c|}{ CONTROL BEAMS } \\
\hline ULB & - & - & 0.194 & 0.495 & 2.55 \\
\hline SLB & 116 & 180 & 0.740 & 2.068 & 2.79 \\
\hline
\end{tabular}

\section{Conclusion}

The following conclusion were deduced from the study:

1. The flexural strength of the Apa reinforced lateritic soil beams (ALB) at $4 \%$ is $0.763 \mathrm{~N} / \mathrm{mm}^{2}$ with corresponding load capacity of $3.435 \mathrm{kN}$ which is higher than the steel reinforced lateritic soil beams (SLB) of $0.740 \mathrm{~N} / \mathrm{mm}^{2}$ with corresponding load capacity of $3.329 \mathrm{kN}$. BS 8110-1 [17] requires that area of reinforcement for beams should not exceed 4\%. This report shows that Apa timber at 4 percent area can be used as a reinforcing material in earth.

2. The higher the percentage area of Apa reinforcements used in Lateritic soil beams, the higher the load-bearing capacity.

\section{Recommendation}

Further research should be carried out on:

1. Determining the flexural strength behaviour of Apa timber reinforced lateritic soil beam beyond a beam length of $500 \mathrm{~mm}$.

2. Determining the swelling and shrinkage characteristic of Apa timber and how to improve the bond between the timber and earth.

3. Bond linearity and fatigue analysis of Apa reinforced lateritic soil beam.

4. Study of fire resistance capacity of Apa reinforced lateritic soil beam. 


\section{References}

1. Thagesen, B., Tropical Rocks and Soils, in: Highway and Traffic Engineering in Developing Countries, London: ed. Chapman and Hall, 1996.

2. Lambe, T. W. and Whitman, V. R., Soil Mechanics, New York: diversion John Wiley and Sons Inc, 1979.

3. Kaze, R.C., Microstructure and Engineering Properties of $\mathrm{Fe}_{2} \mathrm{O}_{3}(\mathrm{FeO})-\mathrm{Al}_{2} \mathrm{O}_{3}-\mathrm{SiO}_{2}$ based Polymer Composite, Journal of Cleaner Production, 199(1), 2018, pp. 849-859.

4. NCP 2., Nigerian Standard Code of Practice; The Use of Timber for Construction, Lagos: Nigerian Standards Organisation, Federal Ministries of Industries, 1973.

5. Jimoh, A.A., Rahmon, R.O., and Joseph, S.G., Evaluation of Compressive Strength Characteristics of Structural-sized Apa (Afzelia bipindensis) and Opon (Lannea schimperi) Timber Species Columns found in Nigeria, Journal of Applied Sciences and Environmental Management (JASEM). 21(7), 2017, pp. 1281-1285.

6. Aguwa, J. I., Reliability Assessment of the Nigerian Apa (Afzelia Bipindensis) Timber Bridge Beam Subjected to Bending and Deflection Under the Ultimate Limit State of Loading, International Journal of Engineering and Technology (IJET), 2(6), 2012, pp. 1076-1088.

7. Ozigi, P.B., Jimoh, A.A., Rahmon, R.O., and Babatunde, O.Y., Investigation on some Physical and Mechanical Properties of Apa (Afzelia Bipindensis) Timber grown in Kwara State, Nigeria, USEP: Journal of Research Information in Civil Engineering, 15(1), 2017, pp. 2027-2044.
8. Richard, A.S., Manette, N., Kallenama, A.K., and James, A., Experimental Behaviour of Reinforced Sugarcane Bagasse Ash Laterised Concrete Beam without Shear Reinforcement, International Journal of Civil and Environmental Research, 4(1), 2014, pp. 133-140.

9. Graeme, N., Earth as a Building Material,Waltakere City Council's Sustainable Home Guidelines, 2008

10. BS EN 12390-5., Testing Hardened Concrete. Flexural Strength of Test Specimens, London: British Standard Institution, 2000.

11. BS 1377: Part 2, Soils for Civil Engineering Purposes, London: British Standard Institution, 1990.

12. BS 373. Methods of Testing Small Clear Specimens of Timbers, London: British Standard Institution, 1957.

13. BS 1881-116, Method for Determination of Compressive Strength of Concrete Cubes, London: British Standards Institution., 1983

14. Neville, A.M., Properties of Concrete, Fifth Edition, 2234-2236, 2011.

15. AASHTO (1986), Standard Specifications for Transportation Materials and Method of Testing and Sampling, American Association of State Highway and Transportation Officials, Washington D.C., U.S.A.

16. Sackey, K. A., An Evaluation of the Characteristics of Stabilized Poured Laterite Beams Reinforced with Polypropylene Rope, MSc. Thesis, Ahmadu Bello University, Department of Building, Zaria, 2015.

17. BS 8110-1, Structural Use of Concrete, Code of Practice for Design and Construction, Part 1, British Standards Institution, London, United Kingdom, 1997. 